\title{
SURFACE STERILIZATION PROTOCOL FOR Curcuma angustifolia ROXB. MICROPROPAGATION
}

\author{
Ningthoujam Sandhyarani Devi*1, RK Imotomba ${ }^{2}$, Rocky Thokchom ${ }^{3}$ \\ ${ }^{1}$ Department of Biotechnology, Pandit Deen Dayal Upadhyay Institute of Agricultural Sciences, Bishnupur-795134, Manipur \\ ${ }^{2}$ Pandit Deen Dayal Upadhyay Institute of Agricultural Sciences, Bishnupur-795134, Manipur \\ ${ }^{3}$ Department of Horticulture, Pandit Deen Dayal Upadhyay Institute of Agricultural Sciences, Bishnupur-795134, Manipur
}

Received - July 27, 2018; Revision - August 23, 2018; Accepted - September 20, 2018

Available Online - October 5, 2018

DOI: http://dx.doi.org/10.18006/2018.6(5).890.894

\author{
KEYWORDS \\ Curcuma angustifolia \\ Explant \\ Sterilization \\ Contamination \\ Sterilant
}

\begin{abstract}
For the micropropagation of Curcuma angustifolia usually rhizome buds are used as explants which are definitely associated with various types of soil-born microorganisms, therefore only one type of sterilant cannot be used for the sterilization of these rhizome buds. Therefore present investigation was carried out to develop the most effective surface sterilization protocol for C. angustifolia. In the present study, explants were treated with three sterilizing agents viz., fungicide (Dhanustin) at $1 \%(\mathrm{~m} / \mathrm{v}), 70 \%$ (v/v) ethanol and mercuric chloride $\left(\mathrm{HgCl}_{2}\right)$ at a concentration of $0.1 \%(\mathrm{~m} / \mathrm{v})$. Among the different used sterilants with varying treatment time, $1 \%(\mathrm{~m} / \mathrm{v})$ fungicide with 4 drops of Tween 20 for 30 minutes followed by $70 \%$ alcohol for 1 minute and lastly $0.1 \%(\mathrm{~m} / \mathrm{v}) \mathrm{HgCl}_{2}$ for 10 minutes was found most effective surface sterilizing combination for $C$. angustifolia micorpopagation.
\end{abstract}

* Corresponding author

E-mail: sandhyarani.nin@gmail.com (Ningthoujam Sandhyarani Devi)

Peer review under responsibility of Journal of Experimental Biology and Agricultural Sciences.

Production and Hosting by Horizon Publisher India [HPI] (http://www.horizonpublisherindia.in/).

All rights reserved.
All the article published by Journal of Experimental Biology and Agricultural Sciences is licensed under a Creative Commons Attribution-NonCommercial 4.0 International License Based on a work at www.jebas.org.

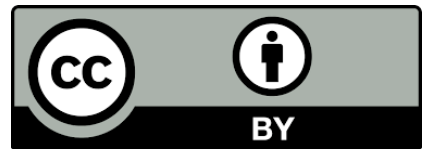




\section{Introduction}

Curcuma angustifolia Roxb. belongs to the family Zingiberaceae and it distributed throughout central, southern and eastern India but most commonly reported from the Northeast and Western Coastal Plains of India (Srivastava et al., 2006; Sharma, 2012). It is generally known as East Indian Arrowroot due to its heritage being considered from the Indian subcontinent. Further, it is also known by various names in different languages such as 'Narrowleaved turmeric' in English, 'Tikhur' in Hindi and 'Yaipan' in Manipuri. The rhizome contributes a major role in its nutritional and medicinal field. This rhizomatous plant is used to ease cough and heal bronchitis and is highly effective on diarrhoea and dysentery (Patel et al., 2015). The essential oil extracted from various plant parts also has antifungal and antibacterial activities (Doble et al., 2011). Further, Shukla et al. (2011) reported antimicrobial properties of $C$. angustifolia leaf essential oil. Phytochemical constituents of $C$. angustifolia are studied by various researchers and reported the presence of ar-curcumin, $\beta$ pipene, $\alpha$-terpineol, camphor, zingirol and borneol (Banerjee et al., 1980). However, Nguyen et al. (2001) reported more than 30 compounds from dried and fresh rhizome of $C$. angustifolia. Jena et al. (2017) also reported the presence of curzerenone, cadinene and $\gamma$-endesmol acetate as the main constituents in leaf oil and curzerenone, camphor and germacrone as major component in rhizome oil. Besides having various medicinal values, biochemical constituents are less exploited. In Manipur, the flowers of this herb are also used as a delicacy in various dishes due to its distinct intriguing taste and it is popularly used in a chutney known as 'Eromba'.

This medicinal herb is naturally propagated mainly through rhizomes and in vitro propagation techniques via plant tissue culture. Natural propagation method of Curcuma species are very slow process compared to the opportunity offered by plant tissue culture techniques. Tissue culture protocol for various Curcuma species such as C. amada (Borthakur \& Bordoloi, 1992; Nayak, 2001; Prakash et al., 2004; Shukla et al., 2007), C. aromatica (Nayak, 2000), C. longa (Nadgauda et al., 1978; Balachandran et al., 1990, Salvi et al., 2002; Rahman et al., 2004;Prathanturarug et al., 2005), C. zedoaria (Loc et al., 2005) and C. spp. (Yasuda et al., 1988; Tyagi et al., 2004) has been developed by various researchers. For a successful and effective micropropagation method, an efficient explant sterilization step should be established (Traore et al., 2005). Surface sterilization of the naturally contaminated living plant materials from the environment is a critical step since it involves the use of chemical solutions like sodium hypochlorite, ethanol, mercuric chloride etc. that are toxic to the plant tissues (George, 1993). Types, amount and exposure time of the sterilants are important for the establishment of a contamination free sterilization protocol.
Higher concentration of these sterilants is also responsible for lower growth and viability of explants. Therefore, present investigation has been conducted to develop a simple surface sterilization protocol for in vitro culturing of $C$. angustifolia.

\section{Materials and Methods}

\subsection{Plant Materials}

Plants of C. angustifolia (Figure 1A) were collected from Bishnupur District of Manipur $\left(23^{\circ} 50^{\prime}-24^{\circ} 43^{\prime} \mathrm{N} ; 92^{\circ} 58^{\prime}-94^{\circ} 45^{\prime} \mathrm{E}\right)$ and maintained in the Botanical Field of Pandit Deen Dayal Upadhyay Institute of Agricultural Sciences, Utlou, Manipur. The plants were identified taxonomically by experts.

\subsection{Culture Medium}

For micropropagation, MS medium (Murashige \& Skoog, 1962) containing $3 \%(\mathrm{w} / \mathrm{v})$ sucrose and $0.8 \%(\mathrm{w} / \mathrm{v})$ Agar (Hi-media, Mumbai, India) fortified with various concentration and combination of $\alpha$-nephthalene acetic acid (NAA), 6-benzylamino purine (BAP) were used. All the growth regulators were purchased from Sigma (St. Louis, MO, USA). Prior to gelling with agar the $\mathrm{pH}$ of the medium was adjusted to 5.8 using $1 \mathrm{~N}$ $\mathrm{NaOH}$ and $1 \mathrm{~N} \mathrm{HCl}$ and sterilized by autoclaving at $121^{\circ} \mathrm{C}$ and $1.05 \mathrm{Kgcm}^{-2}$ pressures for 20 mins.

\subsection{Explant sterilization}

The rhizome axillary buds were cut into small blocks having a bud each. Before surface sterilization the explants were washed in Tween 20 detergent solution for $30 \mathrm{~min}$ and further rinsed with tap water followed by treatment with $1(\mathrm{~m} / \mathrm{v}) \%$ Dhanustin (fungicide) for $30 \mathrm{~min}$ and again rinsed with distilled water for 34 times. The rhizome buds were trimmed into smaller sized cubes under the Laminar Air Flow chamber and subjected to different treatment duration regime of $70 \%(\mathrm{v} / \mathrm{v})$ alcohol and $0.1 \%$ $\mathrm{HgCl}_{2}(\mathrm{~m} / \mathrm{v})$. In the first experiment the buds were treated with 70 $\%$ (v/v) alcohol for 0.5 minutes followed by rinsing 2-3 times with sterilized distilled water and finally treated with $0.1 \%(\mathrm{~m} / \mathrm{v})$ $\mathrm{HgCl}_{2}$ subsequently for 5,7 and 10 minutes. Later on exposure time for $70 \%$ alcohol was increased to 1 minute followed by 0.1 $\%(\mathrm{~m} / \mathrm{v}) \mathrm{HgCl}_{2}$ for $5,7,10$ and 12 minutes.

\section{Results and discussion}

In this experiment, $C$. angustifolia was subjected to eight different treatment regimes using MS (Murashige \& Skoog, 1962) medium supplemented with different concentrations and combinations of naphthalene acetic acid (NAA) and benzyl aminopurine (BAP). Effect of exposure time duration and various combinations of sterilants on explants contamination (\%) and survival rate of the explants $(\%)$ have been represented in Table 1. Highest 
Table 1 Influence of different sterilants on survival percentage, contamination percentage, explants colour and growth type after 21 days of culture

\begin{tabular}{|ccccccc|}
\hline Time duration (minute) & & a Contamination & a & Suvival \\
$(\%)$ & Culture Colour & Growth Type \\
\hline 30 & 0.5 & 5 & 100 & 0 & Creamish & Dead \\
\hline 30 & 0.5 & 7 & 80 & 20 & Creamish & Morbid \\
\hline 30 & 0.5 & 10 & 70 & 30 & Normal & Corrugated \\
\hline 30 & 1 & 5 & 40 & 60 & Normal & Corrugated \\
\hline 30 & 1 & 7 & 20 & 80 & Normal & Vigorous \\
\hline 30 & 1 & 10 & 0 & 100 & Normal & Vigorous \\
\hline 30 & 1 & 12 & 0 & 30 & Blackish & Morbid \\
\hline 15 & 1 & 10 & 70 & 30 & Normal & Corrugated \\
\hline
\end{tabular}

${ }^{\mathrm{a}}$ Values are the average of 10 explants/treatment
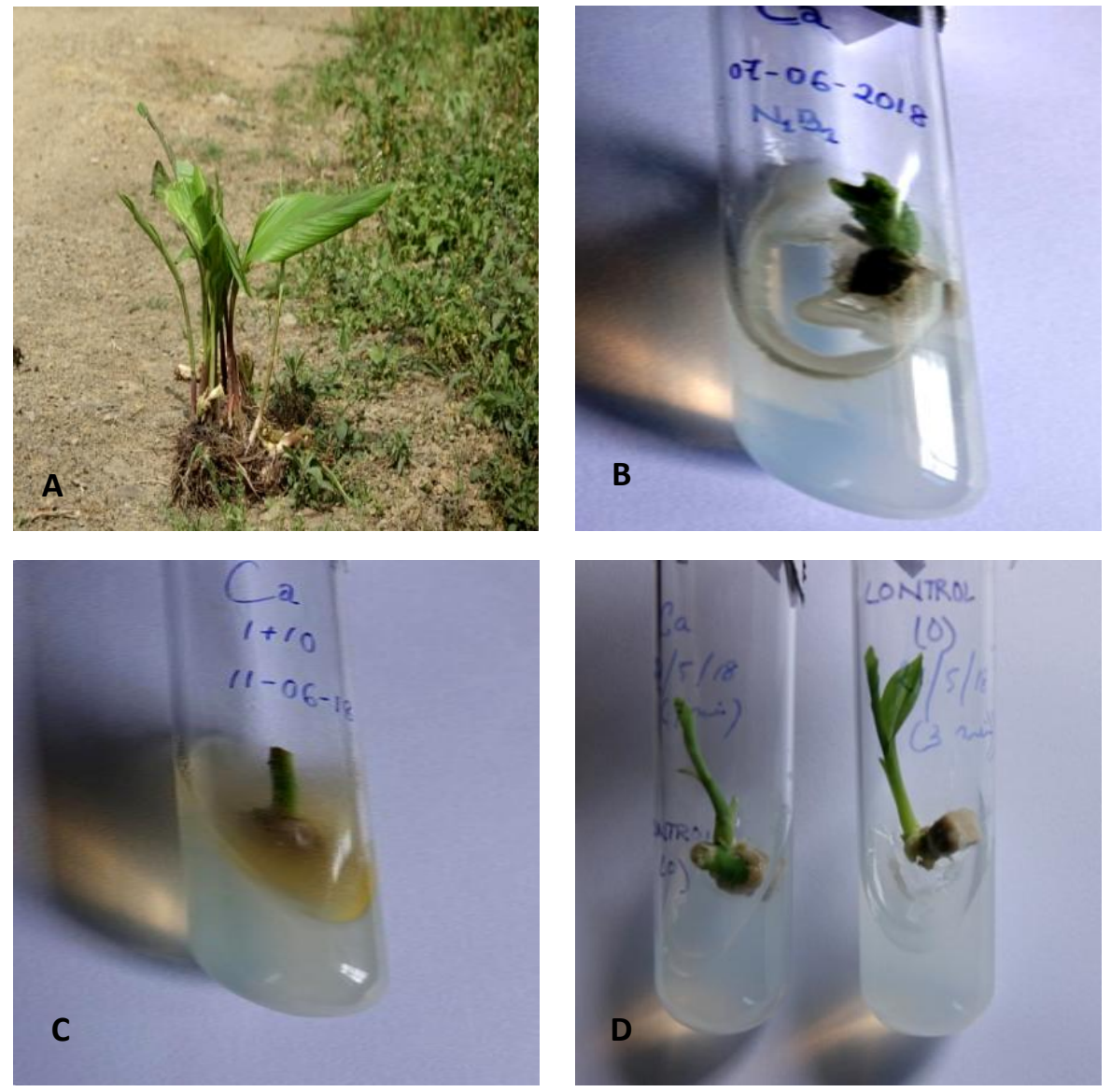

Figure 1: Curcuma angustifolia plants and Response of the explants after treatment with different sterilants with varying time duration. A Plants of Curcuma angustifolia collected from natural habitat. B. Tween 20 with $1 \%$ fungicide for 30 min followed by $70 \%$ alcohol for $1 \mathrm{~min}$ and $0.1 \% \mathrm{HgCl}_{2}$ for $5 \mathrm{~min}$. C. Tween 20 with $1 \%$ fungicide for $15 \mathrm{~min}$ followed by $70 \%$ alcohol for $1 \mathrm{~min}$ and $0.1 \% \mathrm{HgCl} 2$ for $10 \mathrm{mim}$. D. Tween 20 with $1 \%$ fungicide for $30 \mathrm{~min}$ followed by $70 \%$ alcohol for $1 \mathrm{~min}$ and $0.1 \% \mathrm{HgCl} 2$ for $10 \mathrm{~min}$ showing vigorous growth. 
percentage of contamination $(100 \%)$ was observed when the explants were treated with $0.1 \%(\mathrm{~m} / \mathrm{v}) \mathrm{HgCl}_{2}$ for 5 minutes followed by $70 \%(\mathrm{v} / \mathrm{v})$ alcohol for 30 seconds. At this concentration, cultures got bacterial (Figure 1B) as well as some fungal contamination (Figure 1C) which may be because of less treatment time with $\mathrm{HgCl}_{2}$ and $70 \%$ alcohol. The highest survival percentage $(100 \%)$ was achieved when explants were subjected to Tween 20 and $1 \%(\mathrm{~m} / \mathrm{v})$ fungicide solution for 30 minutes followed by treatment with $70 \%(\mathrm{v} / \mathrm{v})$ alcohol for 1 minute then washing with $0.1 \%(\mathrm{~m} / \mathrm{v}) \mathrm{HgCl}_{2}$ for 10 minutes which showed fresh and vigorous growth (Figure 1D). It was observed that treatment with $70 \%$ alcohol less than 1 minute showed higher contamination compared to treatment for 1 minute. This may be because of weaker chemical effect due to shorter exposure duration that was unable to kill the pathogens present in the explant. Highest mortality percentage was obtained when the explants were treated with $0.1 \% \mathrm{HgCl}_{2}$ for 10 minutes. Treatment with $0.1 \% \mathrm{HgCl}_{2}$ for more than 10 minutes resulted into death and desicated cultures. The use of mercuric chloride as a sterilizing agent has been frequently reported (Naika \& Krishna, 2008; Preethi et al., 2011; Anburaj et al., 2011). However, exposure of $\mathrm{HgCl}_{2}$ had negative effects on survival rate of explants (Danso et al., 2011). Longer period of exposure with $\mathrm{HgCl}_{2}$ leads the browning of explants and death. Our report had the same parallel effect with the previous studies (Wesely et al., 2011; Johnson et al., 2011).

Surface sterilization of the plant materials from the environment is a critical step since it involves the use of chemicals like fungicide, ethanol and mercuric chloride which are toxic to the plant's tissues. Plant species and type of explants are important for the development of proper sterilization protocol. The surface contaminant varies based on the type of natural environment they are inhabiting and age of the plant materials. For in vitro cultures to avoid contamination it is an essential step to standardize an effective sterilization protocol for proper in vitro culturing.

\section{Conclusion}

Sterilization of the rhizome axillary buds of C.angustifolia with $70 \%(\mathrm{v} / \mathrm{v})$ alcohol and $0.1 \%(\mathrm{~m} / \mathrm{v}) \mathrm{HgCl}_{2}$ is very critical as evidenced from this study. Our results show that a combination of $70 \%(\mathrm{v} / \mathrm{v})$ alcohol for 1 minute and $0.1 \%(\mathrm{~m} / \mathrm{v}) \mathrm{HgCl}_{2}$ for 10 minutes is the most effective surface sterilization protocol for in vitro micropropagation of $C$. angustifolia. As very limited reports on in vitro micropropagation, chemical profile and molecular studies are available for this medicinally important plant, there is a great requirement for further investigation.

\section{Conflicts of interest}

No conflicts of interests are declared by authors for the contents in this manuscript.

\section{References}

Anburaj J, Ravider Singh C, Kuberan T, Sundaravadivelan C, Kumar P (2011) Effects of plant growth regulators on callus induction from leaf explants of Cleome viscose. Research Journal of Pharmaceutical Biological and Chemical Sciences 2: 576-583.

Balachandran SR, Bhat SR, Chandel KPS (1990) In vitro clonal propagation of turmeric (Curcuma spp.) and ginger (Zingiber officinale Roxb.). Plant Cell Report 8: 521-524.

Banerjee A, Kual VK, Nigam SS (1980) Riv. Ital. Essenze. Profumi, Piaute Off., Aromat.,Syndets Sapon iCosmet. Aerosols $62: 75-76$.

Borthakur M, Bardoloi DN (1992) Micropropagation of Curcuma amada Roxb. Journal of Spice and Aromatic Crops 1: 154-156.

Danso KE, Azu E, Elegba W, Asumeng A, Amoatey HM, Klu GYP (2011) Effective decontamination and subsequent plantlet regeneration of sugarcane (Sacchrum officinarum L.) in vitro. International Journal of Integrated Biology1: 90-96.

Doble B, Dwivedi S, Dubey K, Joshi H (2011) Pharmacognostical and antimicrobial activity of leaf of Curcuma angustifolia Roxb. International Journal of Drug Discovery and Herbal Research 1: 46-49.

George F (1993) Plant propagation by tissue culture.Exergetics Ltd. England: Edington.

Jena S, Ray A, Banerjee A, Sahoo A, Nasim N, Sahoo S, Kar B, Patnaik J, Panda PC, Nayak S (2017) Chemical composition and antioxidant activity of essential oil from leaves and rhizomes of Curcuma angustifolia Roxb. Natural Product Research $31: 2188-2191$.

Johnson M, Wesely EG, Kavitha MS, Uma V (2011) Antibacterial activity of leaves and inter-nodal callus extracts of Mentha arvensis L. Asian Pacific Journal of Tropical Medicine 4: 196-200.

Loc NH, Duc DT, Kwon TH, Yang MS (2005) Micropropagation of Zedoary (Curcuma zedoaria Roscoe): A valuable medicinal plant. Plant Cell Tissue and Organ Culture 81: 119-122.

Murashige T, Skoog F (1962) A revised medium for rapid growth and bioassays with tobacco tissue cultures. Physiologia Plantarum 15: 473-497.

Nadgauda RS, Mascarenhas AF, Hendre RR, Jagannathan V (1978) Rapid multiplication of turmeric (Curcuma longaLinn.) plants by tissue culture. Indian Journal of Experimental Biology 16: $120-122$. 
Naika HR, Krishna V (2008) Plant Regeneration from Callus Culture of Clematis gouriana Roxb. - A Rare Medicinal Plant. Turkish Journal of Biology 32: 99-103.

Nayak S (2000) In vitro multiplication and microrhizome induction of Curcuma aromatic Salisb. Plant Growth Regulation 32: $41-47$.

Nayak S (2001) High frequency in vitro production of microrhizomes of Curcuma amada. Indian Journal of Experimental Biology 40: 230-232.

Nguyen TBT, Trinh DC, Do DR, Nguyen XD (2001) Vietnam Hoa Hoc Va Cong Nghiep Hoa Chat 5: 11-14.

Patel S, Tiwari S, Pisalkar PS, Mishra NK, Naik RK, Khokhar D (2015) Indigenous processing of Tikhur (Curcuma angustifolia Roxb.) for the extraction of starch in Baster, Chhattisgarh. Indian Journal of Natural Product Resources 6:213-220.

Prakash S, Elangomathavan R, Sesadri S, Kathiravan K, Ignachimuthu S (2004) Efficient regeneration of Curcuma amada Roxb., Plantlets from rhizomes and leaf sheath explants. Plant Cell Tissue and Organ Culture 78: 159-165.

Prathanturarug S, Soonthornchareonnon N, Chaukul W, Phaidee Y, Saralamp P (2005) Rapid micropropagation of Curcuma longa using bud explants pre-cultured in thiadiazuron-supplemented liquid medium. Plant Cell Tissue and Organ Culture 80: 347-351.

Preethi D, Sridhar T M, Naidu C V (2011) Efficient Protocol for Indirect Shoot Regeneration from Leaf Explants of Steviare baudiana (Bert.)- An Important Calorie Free Biosweetner. Journal of Phytology3: 56-60.

Rahman MM, Amin MN, Jahan HS, Ahmed R (2004) In vitro Regeneration of plantlets of Curcuma longa Linn.: A valuable spice plant in Bangladesh. Asian Journal of Plant Science 3: 306-309.

Salvi ND, George L, Eapen S (2002) Micropropagation and field evaluation of micropropropagated plants of turmeric. Plant Cell Tissue and Organ Culture 68: 143-151.

Sharma A (2012) Traditional processing of Shotti (Curcuma augustifolia Roxb.)-a rhizome based ethnic weaning food. Indian Journal of Traditional Knowledge 11: 154-155.

Shukla AC, Pandey KP, Mishra RK, Dikshit A, Shukla N (2011) Broad spectrum antimycotic plant as a potential source of therapeutic agent. Natural Product Journal 4: 42-50.

Shukla SK, Shukla S, Vijaya K, Mishra SK (2007) In vitro propagation of tikhur (Curcuma angustifolia Roxb.): A starch yielding plant. Indian Journal of Biotechnology 6: 274-276.

Srivastava AK, Srivastava SK, Syamsundar KV (2006) Volatile composition of Curcuma angustifolia Roxb. rhizome from central and southern India. Flavour and Fragrance Journal 21: 423-426.

Traore A, Xing Z, Bonser A, Carlson J (2005) Optimizing a protocol for sterilization and in vitro establishment of vegetative buds from immature Douglas fir trees. Horticultural Science 40: 1464-1468.

Tyagi RK, Yusuf A, Dua P, Agrawal A (2017) In vitro plant regeneration and genotype conservation of eight wild species of Curcuma. Biologia Plantarum 48: 129-132.

Wesely EG, Johnson M, Kavitha MS, Selvan N (2011) Micropropagation of Alternanthera sessilis (L.) using shoot tip and nodal segments. Iran Journal of Biotechnology 9: 206-212.

Yasuda K, Tsuda T, Shimizu H, Sugaya A (1988) Multiplication of Curcuma species by tissue culture. Planta Medica 54: 75-79. 